\title{
OVERVIEW OF LEGAL FRAMEWORK OF PUBLIC PRIVATE PARTNERSHIPS IN ALBANIA
}

\author{
Ermira Lleshi ${ }^{1}$
}

\begin{abstract}
Albania has made positive steps in improving the legal framework of Public Private Partnerships (PPPs) and the political environment. The laws have encountered several amendments in the last 10 years, but there is still room for improvement. Albania has incorporated the EU directives and the UNCITRAL recommendations into PPPs legislation and we have to admit the effectiveness of the law 125/2013 "On concessions and public private partnership." This paper aims to present a view of the actual legal and sublegal framework of PPPs in our country and to note the development of this sector in potential benefits for both sectors, private and public.
\end{abstract}

Moreover, judicial quality has improved in Albania even though there is room for further improvement. Moreover, there has been noticed a strengthening of institutional capacity due to co-ordination of consultants and external advisers, but government agencies are at the early stages of developing PPPs. The political environment for PPPs is favourable, especially in the energy and transport sector. Further improvement is required in the transparency and fairness of procedures in practice.

UDC: 3'34 ; DOI: http://dx.doi.org/10.12955/cbup.v5.1010

Kewords: Albania, Public private partnership, benefits, legal framework, government agencies

\section{Introduction}

Public Private Partnerships (PPPs) are nowadays a very good instrument of the private sector in compliance with the public sector. Many countries are turning to PPPs in order that the private partner helps the public partner in various areas financially. PPPs are used to hide public borrowing, whereas they provide guarantees in long-term state for profits to private companies (Hall, 2014). A PPP is a contract made amongst a public authority and a private partner in which the private partner incomes and exercises features same as a public authority and it is paid by this one for the services of works in long term payment.

Albania is also a country where PPPs have known a great development especially after the year 2000 . They are more used in the field of infrastructure and water. It is clear that governments prefer the method which is most suitable to establish the most money. The aim of Law 125/2013 is to sustain a friendly and sustainable scheme for building up, attracting and facilitating investments, which are realized as public private concessions/partnerships. The legislation is actually a modern one and has different positive aspects that have regulation in the field of public private partnership, but there is still much to be done to improve transparency and to facilitate procedures.

\section{The concept and definition of PPPs}

PPPs are needed to fill the gaps of two other traditional contracts of public administration, such as public procurement and concession. PPPs are the involvement of the private sector in the goods and works generally supported by the public sector. A characteristic of PPPs is the transfer of risk from the public entity to the private entity.

There are various definitions of this concept according to different sources. The PPP Knowledge Lab defines a PPP as "a long-term contract in between a private entity and a government entity, for securing a public asset or service, in which the private party brings a considerable risk management responsibility, and the payment is related to performance" (World Bank, 2014).

According to Investopedia, public partnerships between a public entity and private-sector are used to finance, establish and perform projects (Investopedia, 2017). Otherwise, a public private partnership is a legal contract between the public and private sectors for the arrangement of assets and the distribution of services that assigns responsibilities and risks between the various partners (Partnerships British Columbia, 2003). According to the Law Dictionary, PPPs are projects that will be useful to the public that are partly owned by the public sector and partly by a private entity (The law dictionary, 2017).

\footnotetext{
${ }^{1}$ University of Tirana, Faculty of Law, Tirana, Albania, ermira.lleshi@ yahoo.com
} 
In several countries, the concept of PPP is applied as a guard term for various types of collaboration among a public entity and a private entity, while in other countries there is a clear difference of regime for PPPs and concessions.

As Albania aspires for EU membership, the domestic legislation is aligned with European legislation. On the other hand, EU legislation does not have a definition of PPPs. Generally, the term points out to forms of cooperation between public institutions and private sector which aim to secure funding, building, renewal, administration or conservation of an infrastructure or the arrangement of a service (European Commission, 2004). Regarding the OECD, PPPs are designate as an agreement among the public authority and one or more private entities according to which the private entity distribute the service in such a way that the service distribution objectives of the public authority are regulated with the benefit objectives of the private entity and the success of the alignment depends on an adequate transfer of risk to the private entity (Burger and Hawkesworth, 2011).

According to Law no. 125/2013 "On concession and Public Private Partnership in Albania", a PPP contract means a contract for public works or a contract for public service that fulfils the conditions which designate it as a Public Private Partnership, as stipulated in this law and, which is signed between the Contracting Authority on the one side and economic operator selected as most successful tenderer on the other (Albanian Assembly, 2013).

The main purpose of this joint venture is to develop the efficiency and quality of service and goods.

\section{Differences between PPPs, public work contracts and concessions}

In a perspective, the regulatory framework of PPPs/concessions acts as a lex specialis from the regulatory frame of public procurement. In almost all legislations, the rules of public tenders precede those of PPPs/concessions. It is also obvious that the majority of rules and procedures of public procurement are applied for PPPs/concessions. Governments prefer the method which is appropriate to establish the most value for their money.

The main difference between them is that in public work contracts the risk of success of the work weights on the public authority. Furthermore, there are methods that are applied to secure the value for money (Burger and Hawkesworth, 2011).

It is widely admitted that concessions are one of the types of PPPs, so we cannot pretend to clearly demarcate these two concepts. One of the main differences is the procedure of payment. In the case of PPPs, the public authority pays the private entity for the offered services/works, while in the case of concessions, usually the revenues of the private partner are created by the payment they collect by the sale of product of the concessionaire project to the third parties (Burger and Hawkesworth, 2011).

Another difference between them is the transfer of risk. In some countries, the risk may remain totally on the contracting public authority, but in the case of concessions even if the risk is divided between parties it is mainly held by the private partner. Appropriate risk transfer from the government to the private sector is the main requirement if PPPs are to distribute services of high-quality and with effective cost to consumers and the government (International Monetary Fund, 2004).

\section{The contract of public private partnership according to the Albanian law}

Law no. 125/2013 "On concessions and public private partnership" treats concessions as a form of PPP. As they are treated with the same law, we may say that the public private partnership contracts are global. According to Albanian law, PPPs are a wider concept than concessions, they include concessions but at the same time they are clearly different from them.

\section{- $\quad$ Parties in the PPPs contract}

The two parties of the PPPs contract are the Public Authority and the Economic Operator, according to articles 3/2,3/3,3/22, 3/23 and 8 of "Law no. 125/2013 "On concessions and public private partnership."

In addition, the contracting authorities are stipulated in the above law, meaning the bodies that shall undertake a procedure for concession/PPP. According to article 13 of the law these bodies are: the Parliament, the line ministries, Council of Ministers and the local government authorities. The contractor is the economic operator that is going to sign the contract with the public authority. For purposes of this law, special purpose vehicle can be set up which is a private legal entity with its main office in the Republic of Albania, which is established upon the demand of the Contracting entity by 
the economic operator selected as the most successful tenderer and, with which the contract shall be signed thereof (Albanian Assembly, 2013). The economic operator is the contractor which means the natural person or the legal personal, or group of people or other bodies in the market that offer public work or services. It is obviously deducted by article 8 of the law that concession contracts may be signed between two public bodies, a PPP can be signed only by a public authority and a private partner. In this form of the contract, we have a transfer of the public sectors of a public interest to the private partner. If there is no transfer from public authority to the private partner, of organization, management and accountability of the specific sector of public interest, we do not have to deal with a concession/PPP contract.

\section{- Area of implementation of the law "On concessions and public partnership" in Albania}

As we mentioned above, the PPPs are applicable in realization of works and also in services. It is stipulated in article 4 of the law the concrete area where this kind of contract is implemented in Albania. The areas are: all types of transport; distribution of electricity and energy; production and distribution of water; waste management, including their collection, transfer, treatment and disposal; telecommunication; various areas of science and education; areas of tourism, leisure and hospitality; areas of culture, sports, health, social services; prison; rehabilitation of forests; industrial parks, mines and similar business support infrastructure; housing; public administration facilities, IT and database infrastructure; Urban/suburban rehabilitation and development; agriculture. In each case, the Council of Ministers, upon the recommendation of the line ministries or, upon proposals, which they receive from local government units or central bodies of Concessions/PPPs policies, shall decide on the Concessions/PPPs to be implemented in other sectors. (Albanian Assembly, 2013).

Moreover, the law "On concessions and public partnership" envisages the specific cases where it is not implemented, where exemption take place. So, the law shall not apply: under the low monetary threshold; when their achievement must be accompanied by certain security measures in conformity with the laws in force, or when the protection of the State's main interests is required; and for the acquisition or rental, by financial methods, of immovable property. Nevertheless, financial service contracts concluded at the same time as, before, or after the contract of acquisition or rental, in whatever form, shall be subject to the Law; the acquisition, development, production or co-production of program material or commercials intended for broadcasting by broadcasters or publication in the media, and contracts for broadcasting time; Concessions, which are subject to different rules and are awarded pursuant to special procedural rules of international organizations; For arbitration and resolution services; For financial services linked with the sale, purchase or transfer of securities, in particular transactions by contracting authorities to raise money or capital; For air transport; Concessions/PPPs, which are subject to different rules and are awarded in accordance with international accords, which the Albania concluded with several states, signed according the Treaty on the Functioning of the European Union, and which include, supplies, works or services intended for joint application or use the projects by the countries that are members; Concessions/PPPs, which in case that this Law conflicts with an obligation of the State under, or arising out of, an agreement of an international organization, the provisions of that agreement shall dominate. In all other aspects, award procedures and principles shall be governed by this Law; service concessions awarded by a Contracting Authority to another Contracting Authority, or to an association of Contracting Authorities, on the basis of an exclusive right which they enjoy according to the legislation (Albanian Assembly, 2013).

\section{Forms of PPPs in Albania}

Pursuant article 8/4 of the Law, depending on the means of remuneration as well as allocation of key inherent risks, a PPP may be realized either as Public works concession, or Public service concession, or Public works contract, or Public service contract (Albanian Assembly, 2013). These are the forms of a PPP contract and there is no reason to confuse them with the concession or public procurement contract. In the concession contract the remuneration is granting to the concessionaire the right to use the work or service, and in case it is foreseen, it includes a payment by the public authority, and the risk is transferred also to the private entity. Whereas in procurement contract remuneration of private entity is composed by the payment of a price by the public entity and risk is held by the public authority. 


\section{Legal framework of PPPs}

Albania has a specific law that deals with PPPs, whereas there are other countries that do not have a dedicated law. The basic law that elaborates PPPs in Albania is Law no. 125/2013 "On concessions and public partnership." Decision of Council of Ministers no. 575, date 10.07.2013 "On Approval of Rules for Assessment and Granting with Concession / Public Private Partnership." Decision of Council of Ministers no. 130 date 12.03.2014 "On the electronic performing of the competitive procedures of concession/PPP." Decision of Council of Ministers no. 634 date 01.10.2014 "On approval of rules for Assessment and Granting with Concession / Public Private Partnership of public work and services for building, operating, maintenance and rehabilitation of national streets." Decision of Council of Ministers no. 211 date 16.03.2016 "On creating and administrating of electronic register of concession/Public Private Partnership."

Whereas during the public procurement stage, the process is based on legislation for public tenders. So, legislation and by-laws are as followed:

Law no. 9643 date 20.11.2006 "On public procurement," amended. Decision of Council of Ministers no. 914 date 29.12.2014 "On approval of rules of public procurement." Decision of Council of Ministers no. 918 date 29.12.2014 "On performing of electronic procedures of public procurement."

Besides the above legal framework in the PPPs procedures, there are also more general laws which are applied when there is no explanation in the specific laws and sub-ordinates. Thus, the Administrative Code of Procedures and Civil Code are fruity implemented.

Whereas in an institutional view, the competent authorities that are part of a PPP project are the ministries, municipalities and districts. In cases when according to the previsions of the law, the object of contract and specific competencies, competence for a concession project or PPP, can belong more than a public authority that fulfils the conditions to be a contractual authority, then the Council of Ministers with a special decision, assigns the contractual authority or authorities, case by case. ((ATRAKO))

Besides the mentioned authorities, there are more authorities involved in the procedure of concession or PPPs according to their field of competences, such as Council of Ministers, ministry of economy, ministry of finances, Commission on Public Procurement and Agency of Treatment of Concessions.

\section{Legal procedure of PPPs}

There are several steps that must be fulfilled in order to finalize a PPP. The law no. 125/2013 envisages the legal procedure, which is divided in concrete actions pursuant the law. The first phase is the stage of identification of the project, which begins with a proposal for the possibility of a PPP project. The proposals shall come from the public authority competent of the field in which is undertaken the project, other public institutions, organizations, investors, etc. The common is that the proposal must be evaluated by the public authority competent of the field in which the project is undertaken.

It continues with the assessment of the proposed project. This is a stage in which the concrete project is analyzed and an opportunity is made for evaluation in order to realize if the project is possible to be implemented. The competent public authority for the identification, evaluation and granting the project of PPP, according to law no. 125/2013 and the Decision of Council of Ministers no. 575, is the public authority competent for the object of the PPP. This public authority appoints an ad hoc commission. It aims that all the stages of the legal procedures of PPPs are followed by a specific structure and with specialized staff. The commission is in charged to make a prior verification of the project proposed. Regarding the results of this evaluation the commission prepares a report regarding the possibility of the realization of the project and presents it to the public authority. Moreover, pursuant article 19 of Law no. 125/2013, the commission shall prepare the Feasibility Study which consists of an operational summary, general project description, technical financial economic and legal analysis, environmental study and nature implication, and accompanying annexes, required addendums, conclusion and recommendation. In this meaning, the commission gives to the public authority a complete view and a deep analysis of all aspects of the project elements. The results of the Feasibility Study are crucial to 
the public authority because this document serves as a core document to evaluate if the concrete project shall be implemented or not.

If the evaluation of the project gains a positive evaluation, it continues in the other stage, which is the granting of PPP. This stage includes other procedural stages, which begin with the public tender competition and the evaluation of the bids by the private operators. Pursuant article 23 of the law, the most economically viable offer based on various criteria. In the tender documents, it should be envisaged prior the evaluation coefficient and the respective marks, of each of implemented criteria. In case of unsolicited proposals, the proposer shall compete with the other offers. Otherwise, in cases the unsolicited proposer is approved a bonus by Council of Ministers, he competes with a bonus up to $10 \%$ of total points of competition. Tender procedure starts with contract notice which consists of intention of contracting an entity to grant a concession. In cases when this stage is finalized with success, it proceeds with the conclusion of the contract. Before the signing of the contract, there is prior action taken by contracting authority, which guarantee the contract by the private partner, such as the value, form, and manner. This serves as a compensation tool for the damage caused in case that the contract fails.

The conclusion of the contract is the finalization of this process. The duration of the contract shall not extend 35 years according law no.125/2013. The contract shall envisage the rights and obligation of the parties with the general principle of balance of their rights and obligations. The contract should foresee the risks that are foreseen for the implementation of the contract, the division between the two parties. The risks should be charged to the party that is objectively capable to manage it. The contract shall also envisage the conditions regarding the works and services and the mechanisms of payment. Another key element of the contract are the sanctions and penalties in case of violation of contract and the mechanisms for solution of disputes.

The conclusion of the contract is not the final stage because it is included in the stage of management of the contract, monitoring the effective implementation of the contract until the successful implementation of the project.

\section{Advantages of Law no. 125/2013 and by-laws}

The aim of the Law is to provide a positive and sustainable framework for attracting, promoting and helping investments, which are realized as public private concessions/partnerships. The legislation on this field tries to establish a good basis in the field of investments with cooperation among public and private partners. The law relies on these principles: transparency, non-discrimination, proportionality, efficiency, equality, reciprocity and legal security. The principle of transparency is sine qua non for the application of the others. It is closely related with the information, publication and access of public, obliging the public authority to pursue transparent procedures.

The legislation also meets the international standards set out by international bodies such as the United Nations Commission on International Trade Law, Organization for Economic Co-operation and Development, the European Bank for Reconstruction and Development, etc. In contrast with the previous law no. 9663, dated 18.12.2006 "On concessions" the new law is drafted in approximation with the EU legislation and with the assistance of OECD. It is also a law harmonized with the law "On public procurement" and there are no double procedures and standards in the administration of complaints.

\section{Conclusions}

In the infrastructure field, PPPs can improve the quality of the field if they are implemented with transparency and fairness. PPPs transfers the risk of performance to private partner. The usage of this form of cooperation among public and private partners is an encouragement innovation. PPP projects can deliver better value of money. Legislation of PPPs in Albania has known great improvement but, there is still work to be done to strengthen fairness and facilitate procedures.

\section{References}

(ATRAKO), A. o. (n.d.), Retrieved from www.atrako.gov.al.

Albanian Assembly, (2013), Law no. 125/2013 "On concessions and public private partnerships in Albania". Official Journal.

Burger, Philippe; Hawkesworth, Ian, OECD, (2011), How to attain value money: comparing PPP and traditional infrastructure public procurement, OECD Journal on Budgeting, Volume 2011/1, 17. 
David Hall, P. (2014), Why public-private partnerships don't work, The many advantages of the public alternative.

European Commission, (2004), Green Paper on Private Public Partnerships and community law on public contracts and concessions, COM (2004) 327 final,. Brussels.

International Monetary Fund, (2004), Public Private Partnership. International Monetary Fund.

Investopedia. (2017), Retrieved from Investopedia: http://www.investopedia.com/terms/p/public-private-partnerships.asp

Partnerships British Columbia, (2003), An introduction to public private partnerships. Canada: Partnerships British Columbia.

The law dictionary, (2017), Retrieved from http://thelawdictionary.org

World Bank, (2014), Retrieved from PPP Knowledge Lab: https://pppknowledgelab.org/ppp-cycle/what-ppp 